\title{
Article
}

\section{Polypodium vulgare L.: polyphenolic profile, cytotoxicity and cytoprotective properties in different cell lines}

\author{
Adrià Farràs ${ }^{1,2}$, Víctor López ${ }^{2,4}$, Filippo Maggi ${ }^{3}$, Giovani Caprioli ${ }^{3}$, M.P. Vinardell ${ }^{1}$, Montserrat Mitjans ${ }^{1 *}$ \\ 1Department of Biochemistry and Physiology, Faculty of Pharmacy and Food Sciences, Universitat de \\ Barcelona, 08028 Barcelona, Spain; afarrama7@alumnes.ub.edu (A.F.); mpvinardellmh@ub.edu (P.V.); \\ montsemitjans@ub.edu (M.M.) \\ 2Department of Pharmacy, Faculty of Health Sciences, Universidad San Jorge, Villanueva de Gállego, \\ Zaragoza, 50830 Spain; afarrama7@alumnes.ub.edu (A.F.); ilopez@usj.es (V.L.) \\ ${ }_{3}^{3}$ chool of Pharmacy, Università di Camerino, 62032 Camerino, Italy; filippo.maggi@unicam.it (F.M.); \\ giovanni.caprioli@unicam.it (G.C.) \\ ${ }^{4}$ Instituto Agroalimentario de Aragón-IA2, CITA-Universidad de Zaragoza, 50013 Zaragoza, Spain \\ *Correspondence: montsemitjans@ub.edu
}

\begin{abstract}
Pteridophytes, represented by ferns and allies, are an important phytogenetic bridge between lower and higher plants (gymnosperms and angiosperms). Ferns have evolved independently of any other species in the plant kingdom being its secondary metabolism a reservoir of phytoconstituents characteristic of this taxon. The study of the possible medicinal uses of Polypodium vulgare L. (Polypodiaceae), PV, has increased particularly when in 2008 the European Medicines Agency published a monograph about the rhizome of this species. Thus, our objective is to provide scientific knowledge on the methanolic extract from the fronds of $P$. vulgare L., one of the main ferns described in the Prades Mountains, to contribute to the validation of certain traditional uses. Specifically, we have characterized the methanolic extract of PV fronds (PVM) by HPLC-DAD and investigated its potential cytotoxicity, phototoxicity, ROS production and protective effects against oxidative stress by using in vitro methods. Our results show that PVM is not cytotoxic against the different cell lines assessed, but we found potential cytoprotective and cellular repair activity in 3T3 fibroblast cells. This biological activity could be attributed to the high content of polyphenolic compounds; thus, this extract is positioned as a potential candidate for pharmaceutical uses.
\end{abstract}

Keywords: cytoprotection; cytotoxicity; ferns; oxidative stress; Polypodiaceae; Polypodium vulgare L.; medicinal plants

\section{Introduction}

Oxidative stress is characterized by an imbalance between pro-oxidant agents (free radicals, reactive oxygen species, ROS, or nitrogen species, RNS), generated by the metabolism itself or by the permanent exposure of the organism to the environment, and the system of antioxidant defence. According to its origin, this antioxidant system is classified as endogenous (enzymatic and non-enzymatic systems) or exogenous[1]. The exogenous antioxidant system was defined by Halliwell et al.[2] as "any substance that, when present at low concentrations compared with those of an oxidizable substrate, significantly delays or prevents oxidation of that substrate".

The inability to maintain an adequate redox state, either due to excess production of free radicals or an alteration of the antioxidant system, triggers oxidative damage that affects fundamental biological structures. This state is characterized by alterations in the different biological molecules, carbohydrates, proteins, lipids and mainly in DNA[3]. In this sense, studies have associated oxidative stress with the development of different neurodegenerative diseases, inflammatory bowel disease, cardiovascular diseases, metabolic diseases such as type 2 diabetes and even cancer[4,5]. The reduction of the 
incidence of cancer in population groups with diets rich in polyphenols compared to the absence or a mild diet rich in polyphenols is evidence for the chemopreventive action of plant-based food, as it is through the neutralization of part of the free radicals to the which is exposed our body[6].

Numerous investigations have established the link between sun exposure and skin alterations[7,8]. Today it is well documented that ultraviolet radiation affects animals in different causes, among which oxidative stress, inflammation, erythema, breakdown of the extracellular matrix, wrinkling and skin cancer. But the main effect of this ultraviolet irradiation is the increase in oxidative stress caused by the increase in ROS, which can lead to an imbalance in the endogenous antioxidant system[9]. Being ultraviolet irradiation the main etiology in the development of skin cancer in its two categorizations: melanoma and non-melanoma skin cancers[10]. In a retrospective study between 1970 and 2012 using German cancer registry data, Leiter et al.[11] observed that melanoma and nonmelanoma skin cancers have increased because of repeated and inadequate sun exposure of individuals and thus to an increase in epithelial oxidative stress. The integumentary system, in addition to being the largest organ in the body, is the first physical barrier between the body and the external environment, hence its importance in its proper maintenance. Molecules of natural origin can modulate the behaviour of tumour cells by acting on different pathways of molecular signalling such as the topoisomerase inhibition (genistein[12]), kinase inhibition (apigenin[13]) and modulation of multidrug resistance $\left(2^{\prime}, 4^{\prime}, 6^{\prime}\right.$-triOH-chalcone[14]), among other pathways[15]. The doxorubicin, paclitaxel, vinblastine, etoposide, irinotecan, gemcitabine and methotrexate are medically successful in anticancer therapy, for their security and efficacy, which are part of the list of anticancer agents provided or inspired by nature in recent years[16,17]. In addition, molecules of natural origin, as flavonoids for their safety and accessibility, can also be a potential inspiration to create an original therapeutic or preventive (chemopreventive) for cancer treatment and prevention respectively[18-20].

Ethnopharmacological investigations on traditional Chinese medicine have reported the therapeutic uses of ferns in modern medicine. For that purpose, different bioassays were performed as for example antioxidant (Dryoathyrium boryanum (Willd.) Ching (Athyriaceae family)[21]), acetycholinesterase inhibition (Stenochlaena palustres (Burm. f.) Bedd. (Blechnaceae family)[22]), tyrosinase inhibition (Asplenium adiantum-nigrum L. (Aspleniaceae family)[23]) and anti-tumour activity (Davallia cylindrica Ching (Davalliaceae family)[24]) attributed to some ferns.

The antibiotic activity of hundreds of ferns has also been evaluated in against a great diversity of bacteria[25,26]. Currently, the fern that presents a more detailed phytochemical characterization and evaluation for skin therapeutic uses such as photodermatosis, adjunctive treatment of melasma (as chemopreventive), vitiligo, psoriasis vulgaris and atopic dermatitis, is the aqueous extract of Polypodium leucotomos (PLE) $[27,28]$. This fern belongs to the Polypodiaceae family like the Polypodium vulgare L. (PV)[29,30].

PV, known commonly as "polipodio" in Spain for the shape of its fronds as feet (poly: many and podos: foot), is a fern of the leptosporangiate class belonging to the Polypodiaceae family[31-33]. Since 2008, the rhizome of PV has been accepted by European Medicines Agency (EMA) for its use as expectorant herbal medicine in cough and cold and in cases of occasional constipation[34]. PV has been used as medicinal plant in Europe since ancient times. As example, in the middle of the last century the use of PV rhizome infusion as expectorant or diuretic in traditional Polish medicine is reported[35]. Moreover, the fronds of PV have an ethnoveterinary use for treatment variolous, jaundice and parasitic diseases in Spain[36]. American Indians used PV root tea for the treatment of different kinds of pain[34]. Polypodium leucotomos (PL) rhizome has been described in Spain for relief of the symptoms associated with mild to moderate inflammatory processes of the skin for humans under the tradename Difur ${ }^{\circledR}$ as a traditional herbal medicine[37]. Due to the potent antioxidant activity of PLE tied as a chemopreventive agent[38], we think that 
PV (another fern of Polypodiaceae family) could have phytoconstituents with potential chemopreventive action.

In the present study we want to highlight the insufficient number of studies dealing with ferns in comparison with angiosperms to support their potential uses [24,39]. Hopefully, this study will be a turning point for the promotion of ethnopharmacological studies for validation in the future of the multiple traditional uses of this fern in Spain[40].

A

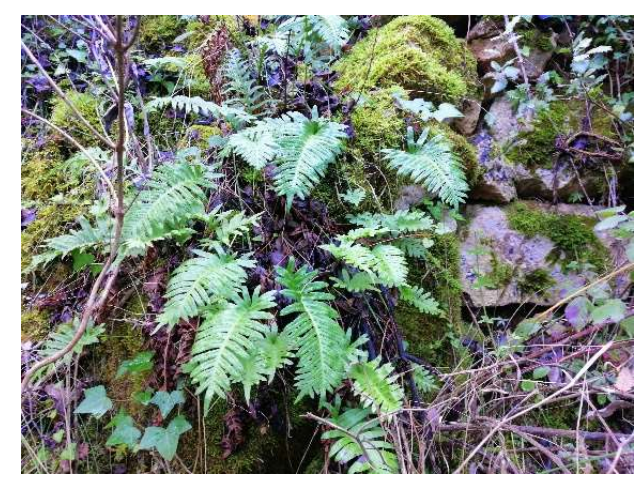

B

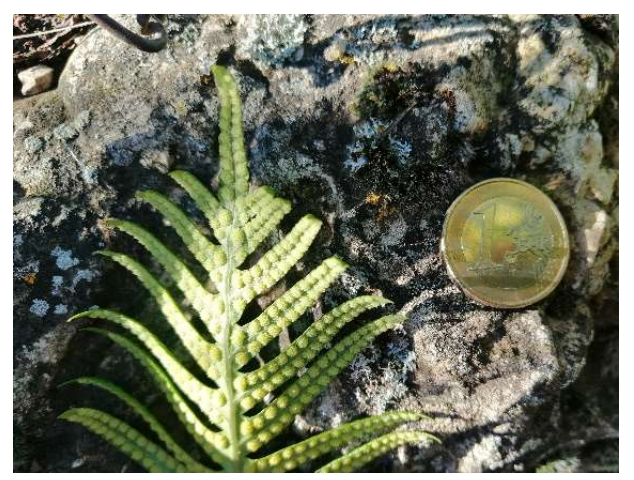

Image 1. Photography of the face fronds (A) and underside frond (B) of fresh Polypodium vulgare L. (Polypodiaceae). Pictures were taken at Prades Mountains. The euro coin reflects the dimension of the frond (image 1B).

\section{Results}

2.1. Phytochemical characterization of PVM by liquid chromatography with diode-array detection (HPLC-DAD)

Different types of polyphenols were monitored in the extract. The extract proved to contain different types of phenolic acids and flavonoids, as observed in Table 1 (77823.7 $\mathrm{mg} / \mathrm{kg}$ ). However, the methanolic extract of fronds of Polypodium vulgare L. did not contain naringin, quercitrin, rosmarinic acid, cinnamic acid, eugenol and trans-cinnamaldheyde.

Table 1. Quantitative determination of metabolites in the methanolic extract Polypodium vulgare L. by HPLC-DAD reported at $272 \mathrm{~nm}$.

\begin{tabular}{|c|c|c|}
\hline $\mathbf{N}^{\circ}$ & Phytochemicals & Quantity (mg/kg extract) a \\
\hline 1 & Shikimic acid & $5339.3 \pm 70.6$ \\
\hline 2 & Gallic acid & $1791.3 \pm 38.3$ \\
\hline 3 & 5-O-caffeoylquinic acid & $256.5 \pm 12.1$ \\
\hline 4 & 3-O-caffeoylquinic acid & $58778.3 \pm 417.7$ \\
\hline 5 & $(+)$-Catechin hydrate & $3879.8 \pm 153.3$ \\
\hline 6 & (-)-Epicatechin & $7158.5 \pm 88.8$ \\
\hline 7 & Rutin & $422.7 \pm 30.4$ \\
\hline 8 & Hyperoside & $91.3 \pm 11.7$ \\
\hline
\end{tabular}


aResults are expressed in $\mathrm{mg} / \mathrm{kg}$ dry extract, $\mathrm{n}=3$.

The major constituents in the PVM extract, as seen in Figure 1, were 3-Ocaffeoylquinic acid (58778.3 $\mathrm{mg} / \mathrm{kg})$, epicatechin $(7158.5 \mathrm{mg} / \mathrm{kg})$ shikimic acid (5339.3 $\mathrm{mg} / \mathrm{kg}$ ) and catechin $(3879.8 \mathrm{mg} / \mathrm{kg}$ ) which were phenol acids. The peculiar secondary metabolites found were hyperoside and 3,5-di-O-caffeoylquinic acid, with low concentrations (91.3 and $106.0 \mathrm{mg} / \mathrm{kg}$ respectively).
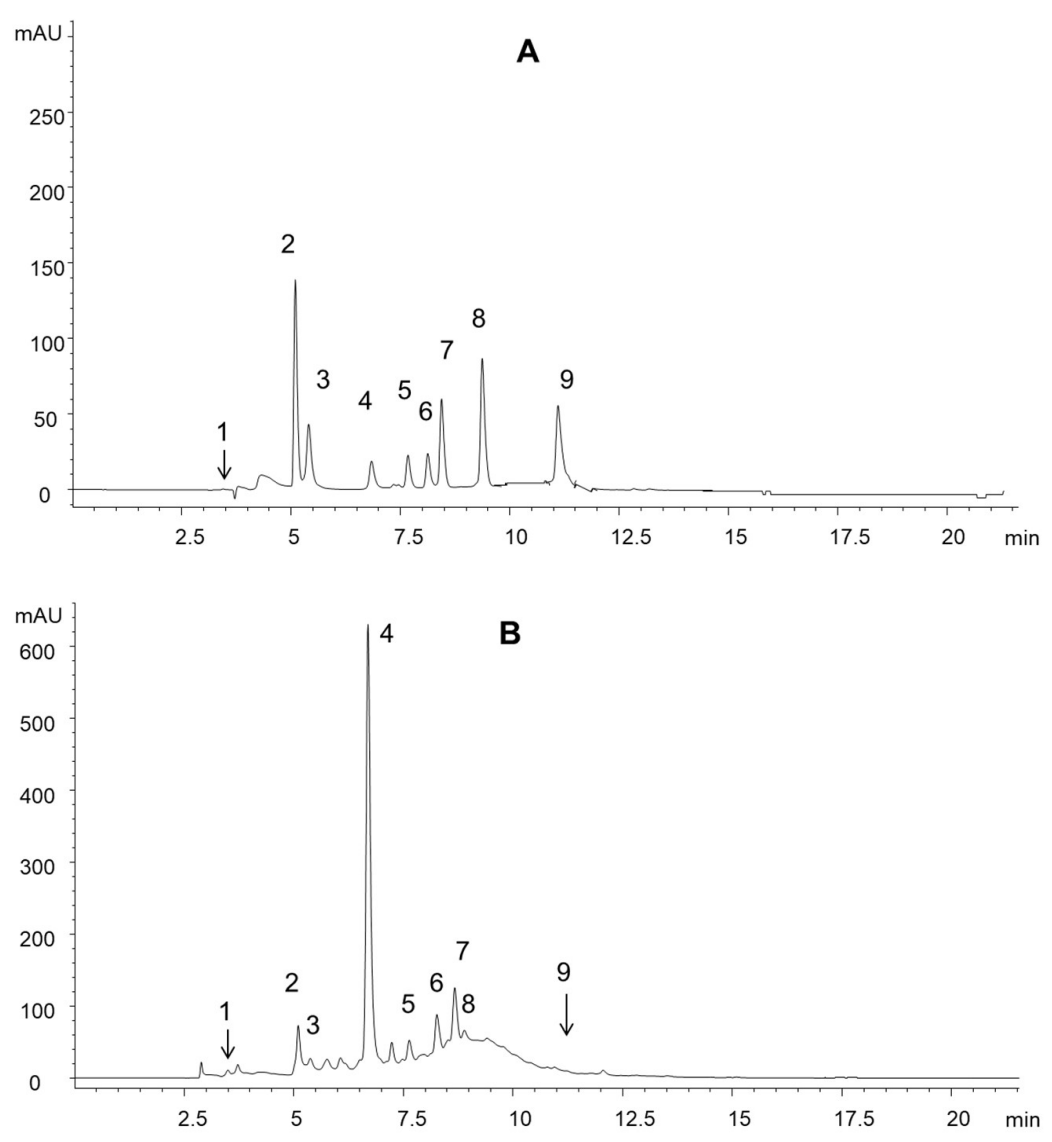

Figure 1. HPLC-DAD chromatograms reported only at $272 \mathrm{~nm}$ for sake of clarity and corresponding to A) standard mixture solution, B) extract of methanolic fronds extract of Polypodium vulgare L. List of compounds: 1 = shikimic acid, 2 = gallic acid, 3 =5-O-caffeoylquinic acid, $4=3$-O-caffeoylquinic acid, 5 = catechin, 6 = epicatechin, 7 = rutin, 8 = hyperoside, $9=3$,5-di-O-caffeoylquinic acid.

\subsection{In vitro cell assays}

Cell viability obtained by the NRU method, show no significant differences between treated and untreated cells independently of the cell line studied (data not shown).

\subsubsection{Cytotoxicity activity of PVM in non-tumoral and tumoral cell lines}

A set of cytotoxic assays was carried out to determine the cytotoxic potential of different range concentrations of PVM $(0.01,0.1,1$ and $2 \mathrm{mg} / \mathrm{mL}$ PVM).

Figure 2 shows the cell viability obtained by the MTT assay for the different cell lines described here. First, we evaluated the cytotoxic activity of the PVM in 3T3 and HaCaT (Figure 2A and 2B) as a representation of non-tumoral cell lines. In both cell lines a marked increase in cytotoxicity was observed, at concentrations of 1 and $2 \mathrm{mg} / \mathrm{mL}$ PVM compared 
to 0.01 and $0.1 \mathrm{mg} / \mathrm{mL}$ PVM but with a slightly higher cytotoxicity activity of PVM in HaCaT (35.3\%) than in $3 \mathrm{~T} 3(46.4 \%)$ at $1 \mathrm{mg} / \mathrm{mL}$ PVM.

A

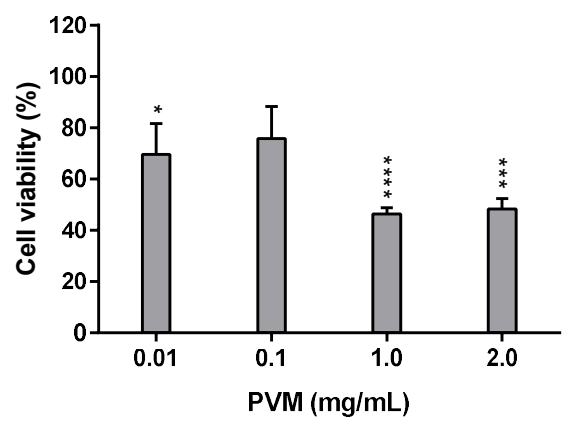

C

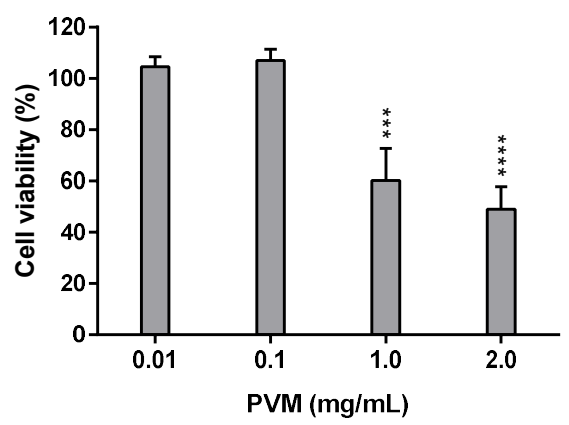

E

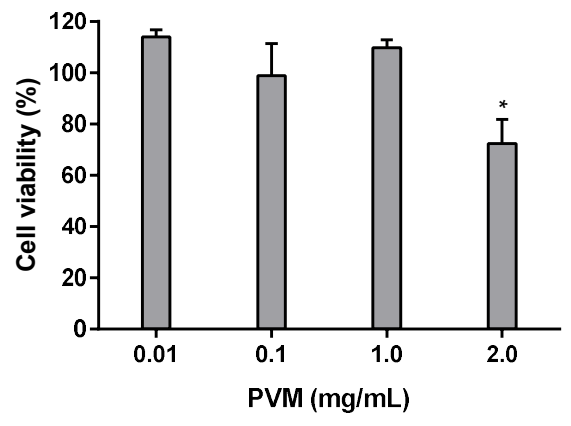

B

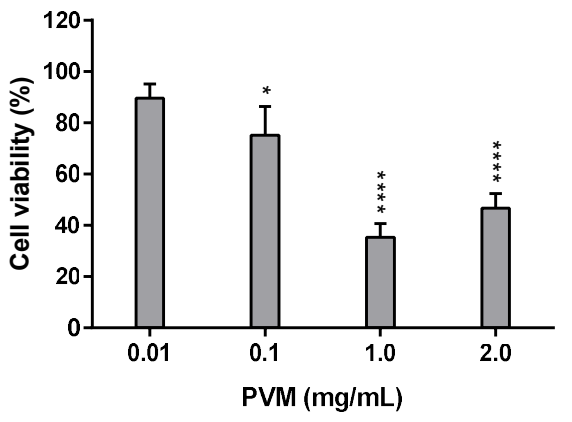

D

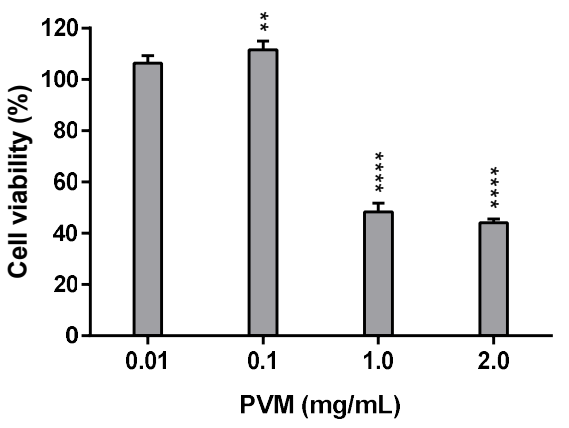

F

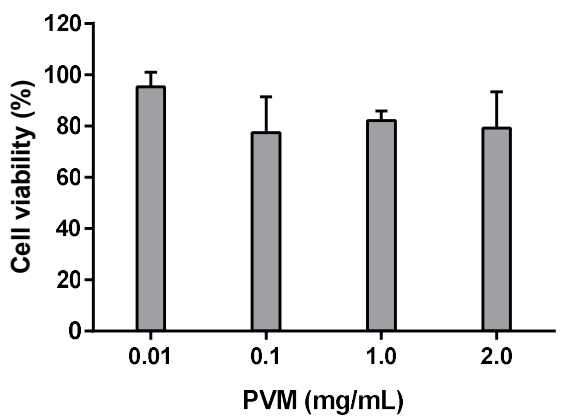

Figure 2. Cytotoxicity activity of PVM in 3T3 (A), HaCaT (B), HeLa (C), HepG2 (D), MCF-7 (E) and A549 (F) cell lines by MTT assay and expressed as percentage of cell viability respect to control cells. Results are expressed as mean \pm standard error of $n=3$. Control cells were maintained only with culture medium. A two-way analysis of variance (ANOVA) and a Bonferroni post hoc assay have been performed. Statistical differences were considered as follows: ${ }^{*} p \leq 0.05,{ }^{* *} p \leq 0.01,{ }^{* * *} p \leq 0.001$ and ${ }^{* * * *} p \leq 0.0001$ compared with no treated cells (negative control).

We extended our PVM cytotoxicity study in tumoral cell lines: HeLa, HepG2, MCF7 and A549. As we can observe in Figure 2C and 2D, PVM on HeLa and HepG2 cells presents a similar cytotoxic behaviour, presenting a significant decrease in cell viability at the highest concentration assessed, being this decrease slightly higher in HepG2 (44.2\%) than HeLa (49.0\%). No cytotoxic effects have been determined at 0.01 and $0.1 \mathrm{mg} / \mathrm{mL}$ of the extract.

In the case of MCF-7 and A549 cells (Figure 2E and 2F) no statistical differences among cell viability is observed at the different concentrations studied of PVM, although 
values show a slight decrease to $72.5 \%$ in MCF-7 at $2 \mathrm{mg} / \mathrm{mL}$ PVM and $77.3 \%$ in A549 at $0.1 \mathrm{mg} / \mathrm{mL}$ PVM.

The present results exhibited that, cytotoxicity effects only appear at 1 and $2 \mathrm{mg} / \mathrm{mL}$ PVM in 3T3, HaCaT, HeLa and HepG2.

\subsubsection{Cytoprotective activity of PVM in $3 \mathrm{~T} 3$ and HaCaT cell lines}

Before the potential cytoprotective activity were studied, the deleterious effects of $\mathrm{H}_{2} \mathrm{O}_{2}$ in $3 \mathrm{~T} 3$ and $\mathrm{HaCaT}$ were initially determined. From this previous assay (data do not show), we have established that cell viability obtained at $2 \mathrm{mM}$ of $\mathrm{H}_{2} \mathrm{O}_{2}$ for $2.5 \mathrm{~h}(30.5 \%$ and $41.0 \%$ for $3 \mathrm{~T} 3$ and $\mathrm{HaCaT}$ respectively) allows us to evaluate potential beneficial effects of PVM.

A

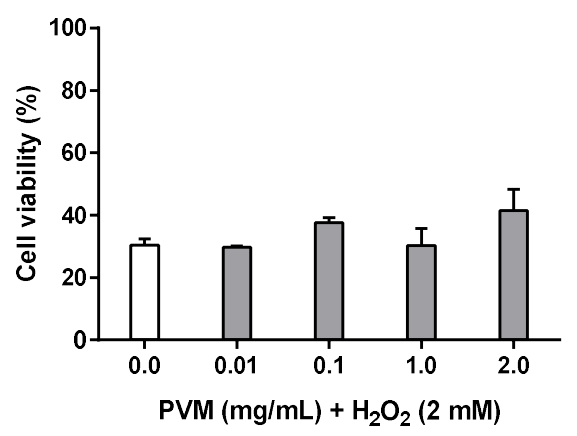

B

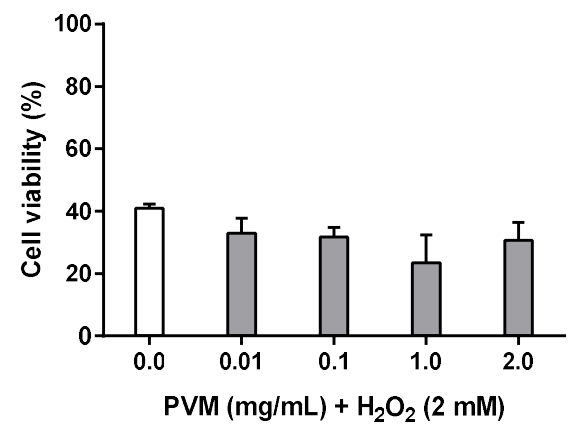

Figure 3. Cytoprotective activity of PVM in $3 \mathrm{~T} 3$ (A) and $\mathrm{HaCaT}$ (B) cell lines for $2 \mathrm{mM} \mathrm{H}_{2} \mathrm{O}_{2}$ during $2.5 \mathrm{~h}$ by MTT assay and expressed as percentage of cell viability respect to untreated cells control. $\mathrm{H}_{2} \mathrm{O}_{2}$ cell viability was used as positive control. Results are expressed as mean \pm - standard error of $\mathrm{n}=3$ and $\mathrm{n}=2$ respectively. A two-way analysis of variance (ANOVA) and a Bonferroni post hoc assay have been performed. No statistically significant differences were found.

As observed in Figure 3A, cell viability in 3T3 increases mainly in parallel to PVM concentration indicating some cytoprotective effect although not statistically significant, being this cytoprotecting activity of $18.9 \%$ and $26.5 \%$ at 0.1 and $2 \mathrm{mg} / \mathrm{mL}$ PVM, respectively. In the case of $\mathrm{HaCaT}$ (Figure 3B), no cytoprotective effect has been observed in any of the concentrations tested since an increase in the PVM concentration has not corresponded to an increase in cell viability.

\subsubsection{Cellular repair activity of PVM in 3T3 tissue cell line}

In the case of the cellular repair assay, we have used the same conditions of $\mathrm{H}_{2} \mathrm{O}_{2}$ as in cytoprotection assay $\left(2 \mathrm{mM} \mathrm{H}_{2} \mathrm{O}_{2}\right.$ for $2.5 \mathrm{~h}$ ). As we can observe in Figure 4 , there is a low increase in cell viability of $3 \mathrm{~T} 3$ as PVM concentration rises, however, this discrete reparation effect is proportional to the concentration of the extract.

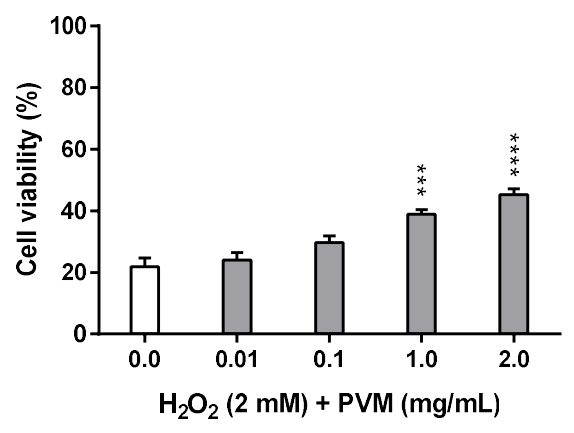


Figure 4. Cellular repair activity of PVM in $3 \mathrm{~T} 3$ cell line for $2 \mathrm{mM} \mathrm{H}_{2} \mathrm{O}_{2}$ during $2.5 \mathrm{~h}$ by MTT assay and expressed as percentage of cell viability respect to untreated cells control. $\mathrm{H}_{2} \mathrm{O}_{2}$ cell viability was used as positive control. Results are expressed as mean \pm- standard error of $n=3$. A two-way analysis of variance (ANOVA) and a Bonferroni post hoc assay have been performed. Statistical differences were considered as follows: ${ }^{* *} p \leq 0.001$ and ${ }^{* * *} p \leq 0.0001$ compared with positive control.

Table 2. Cellular repair activity of PVM in $3 \mathrm{~T} 3$ cell line for $2 \mathrm{mM} \mathrm{H}_{2} \mathrm{O}_{2}$ during $2.5 \mathrm{~h}$ by MTT assay.

\begin{tabular}{ccccc}
\hline Concentration of PVM $(\mathbf{m g} / \mathbf{m L})$ & $\mathbf{0 . 0 1}$ & $\mathbf{0 . 1}$ & $\mathbf{1}$ & $\mathbf{2}$ \\
\hline Cellular repair activity $(\%)^{\mathrm{a}}$ & $8.5 \%$ & $26.1 \%$ & $43.6 \%$ & $51.5 \%$ \\
\hline
\end{tabular}

a Percentage of cellular repair activity has been obtained from the following relation [(CVPVM-H2O2- $C_{\text {H2O2 }}$ / CVPVM-H2O2] $x$ 100 .

\subsubsection{Phototoxicity activity of PVM in $3 \mathrm{~T} 3$ and $\mathrm{HaCaT}$ tissue cell lines}

The validity of the assay has been determined by calculating the ratio of cell viability in irradiated respect to non-irradiated conditions of both negative and positive control cells (Table 3). As observed, a dose of $1.8 \mathrm{~J} / \mathrm{cm}^{2}$ of UVA light affects the viability of nontreated cells that decrease in both cell lines and indicating that 3T3 are much sensitive to light than $\mathrm{HaCaT}$ and that interpretation of data should be interpreted carefully. However, the effect of the photosensitizer CPZ is confirmed by the important drop of cell viability when exposed to UVA. Considering these ratios, the viability obtained when cells were exposed to UVA in the presence of PVM is considered.

Table 3. Comparison of cell viability of irradiated with non-irradiate controlsa.

\begin{tabular}{ccc}
\hline Cell line & DMEM & CPZ \\
\hline 3T3 & $63.3 \%$ & $26.9 \%$ \\
\hline HaCaT & $75.0 \%$ & $13.7 \%$ \\
\hline
\end{tabular}

${ }^{a}$ Expressed as the percentage of cell viability of the irradiated control in relation to the corresponding non-irradiated.

In general, $\mathrm{PVM}$ do not show phototoxic behaviour in the conditions assayed here for 3T3 (Figure 5A) and HaCaT (Figure 5B), except at $0.1 \mathrm{mg} / \mathrm{mL}$ PVM. At this concentration, there is a decrease in viability when cells are exposed to light in a degree of $63.3 \%$ for $3 \mathrm{~T} 3$ and $24.2 \%$ for HaCaT compared to the non-irradiated cells.

A

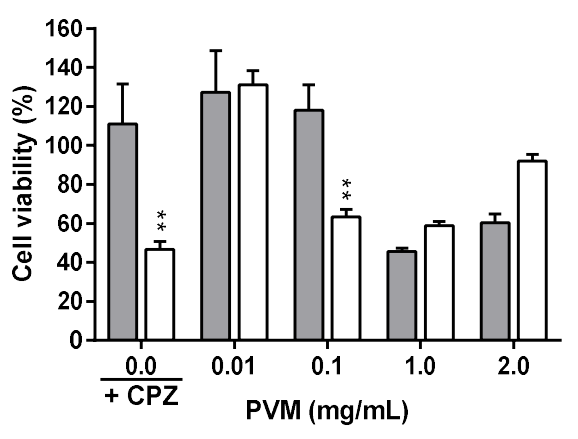

B

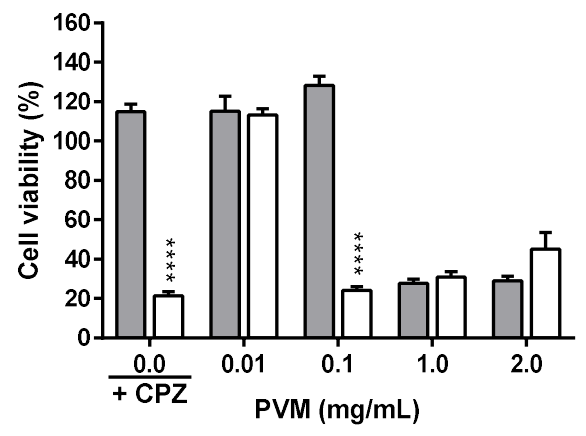

Figure 5. Phototoxicity activity of PVM in 3T3 (A) and HaCaT (B) cell lines by MTT assay and expressed as percentage of cell viability respect to the correspondent control cells. Chloropromazine cell viability was used as positive control. Gray columns correspond to cells non exposed to UVA light and white columns correspond to cells exposed to $1.8 \mathrm{~J} / \mathrm{cm}^{2}$ of UVA light. Results are expressed as mean \pm - standard error of $n=3$. A two-way analysis of variance (ANOVA) and a Bonferroni post 
hoc assay have been performed. Statistical differences were considered as follows: ${ }^{* *} p \leq 0.01$ and ${ }_{* * * *} p \leq 0.0001$ compared with correspondence no irradiated/irradiated positive control.

\subsubsection{Intracellular ROS induced by $\mathrm{H}_{2} \mathrm{O}_{2}$ of PVM in $3 \mathrm{~T} 3$ and $\mathrm{HaCaT}$ cell lines}

The production of ROS was explored by the fluorescence intensity with the DCF probe. As shown in Figure 6, for each cell line was obtained the same tendency of ROS production at $2 \mathrm{~h}$, with similar pattern recorded at $1 \mathrm{~h}$ and $3 \mathrm{~h}$ (data not shown).

A

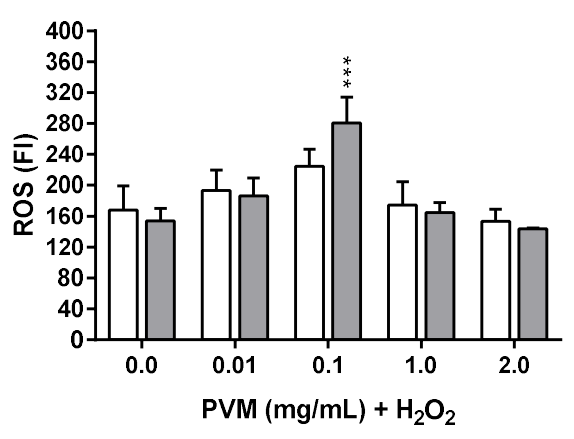

B

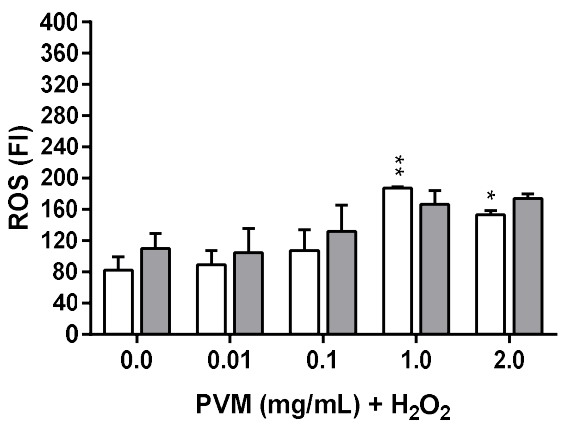

Figure 6. Intracellular ROS induced by 1 and $2 \mathrm{mM} \mathrm{H}_{2} \mathrm{O}_{2}$ for $2 \mathrm{~h}$ treatment with PVM in 3T3 (A) and $\mathrm{HaCaT}(\mathrm{B})$ cells. $\mathrm{H}_{2} \mathrm{O}_{2}$ : positive control. White columns correspond to $1 \mathrm{mM} \mathrm{H}_{2} \mathrm{O}_{2}$ and gray columns correspond to $2 \mathrm{mM} \mathrm{H}_{2} \mathrm{O}_{2}$. Results are expressed as mean \pm - standard error of $n=3$. A two-way analysis of variance (ANOVA) and a Bonferroni post hoc assay have been performed. Statistical differences were considered as follows: ${ }^{*} p \leq 0.05,{ }^{* *} p \leq 0.01$ and ${ }^{* *} p \leq 0.001$ compared with the correspondent positive control.

The production of ROS in the conditions tested here are significantly different for both cell lines (3T3, Figure 6A and HaCaT Figure 6B). In the case of 3T3, positive controls show similar values of ROS production at the two concentrations of $\mathrm{H}_{2} \mathrm{O}_{2}$ but higher than those obtained in the case of HaCaT. This observation suggests that keratinocytes are less sensitive than $3 \mathrm{~T} 3$.

Table 4. Intracellular $\triangle R O S$ induced by 1 and $2 \mathrm{mM} \mathrm{H}_{2} \mathrm{O}_{2}$ for $2 \mathrm{~h}$ respect $0 \mathrm{~h}$ at different concentrations of PVM in $3 \mathrm{~T} 3$ and $\mathrm{HaCaT}$.

\begin{tabular}{|c|c|c|c|c|c|c|c|c|}
\hline \multirow{2}{*}{$\begin{array}{l}\text { Cell line } \\
\text { Concentration of PVM }(\mathrm{mg} / \mathrm{mL})\end{array}$} & \multicolumn{4}{|c|}{$3 \mathrm{~T} 3$} & \multicolumn{4}{|c|}{ HaCaT } \\
\hline & 0.01 & 0.1 & 1 & 2 & 0.01 & 0.1 & 1 & 2 \\
\hline $1 \mathrm{mM} \mathrm{H}_{2} \mathrm{O}_{2}$ & 25.5 & 56.7 & 6.5 & -14.7 & 6.8 & 24.77 & 105.1 & 70.9 \\
\hline $2 \mathrm{mM} \mathrm{H}_{2} \mathrm{O}_{2}$ & 32.3 & 126.7 & 10.5 & -10.7 & -5.1 & 21.7 & 56.8 & 64.1 \\
\hline
\end{tabular}

antracellular $\triangle R O S$ cytoprotective activity has been obtained from the following relation ROSPVM with DCF-H2O2 - ROSDCF-H2O2 expressed as fluorescence intensity (FI).

In Table 4 we show the increment of ROS production in the different conditions. In the case of 3T3 there is a peak of intracellular ROS production in the presence of PVM at $0.1 \mathrm{mg} / \mathrm{mL}$, which is more pronounced in cells treated with $2 \mathrm{mM} \mathrm{H}_{2} \mathrm{O}_{2}$, followed by an important reduction at $1 \mathrm{mg} / \mathrm{mL}$ and, finally, reverted at $2 \mathrm{mg} / \mathrm{mL}$. This pattern is independent of the final concentration of $\mathrm{H}_{2} \mathrm{O}_{2}$. In contrast, the production of ROS is dose dependent in the case of $\mathrm{HaCaT}$, except at $2 \mathrm{mg} / \mathrm{mL} \mathrm{PVM}$ at $1 \mathrm{mM} \mathrm{H}_{2} \mathrm{O}_{2}$. One explanation to this different behavior between the two cell lines can be attributed to the presence of different protective antioxidant systems and that can also explain the ROS production showed by the positive controls (Figure 6).

\section{Discussion}


Despite the significant biological activities attributed to Polypodiaceae family reported in various studies, such as antidiabetic activity (Phymatopteris triloba (Houtt.))[41], antiskin tumor capability as example of anticancer activity (Polypodium leucotomos)[42] and anti-inflammatory activity (Polypodium leucotomos)[27], there are many other Polypodiaceae ferns not yet characterized or studied specifically from their potential medical uses. This is the case of Polypodium vulgare L. (PV). Currently the most studied Polypodiaceae fern is the Polypodium leucotomos (PL) because of the commercialization of its standardized aqueous extract fronds (PLE)[43]. As stated by Messeguer[44], the two major herbal drugs of PV fern are rhizome and fronds as determined in different species of Polypodium ferns reported by Liu[45]. In the present study we have obtained our methanol extract from the fronds of the fern. Some studies reported the isolated phytochemical composition of PV rhizome, describing the different types of phytoconstituents namely flavonoids as flavan3-ol derivatives[46], triterpenoids hydrocarbons, triterpenoids alcohols of the cycloartane group, saponin glycosides (as osladin[47,48]), phytoecdysteroids[44] and others[49]. However, to date no published work or study has dealt with the composition of the PV fronds except Messeguer[44] that described the presence of some phytoecdysteroids. Moreover, it is required a precise phytocharacterization of the PV rhizome because of the large diversity of methodologies and solvents used to obtain the extract. For this reason, we agree with Liu et al.[45] and Sofiane et al.[50] that there is an obvious need for a chemical characterization and standardization of this rhizome extract that it is intended to be used as herbal drug. But to date few articles reporting the phytochemical-activity of this fern have been published. Among them, Sofiane et al.[50] describes antioxidant, antimicrobial and anti-inflammatory activities attributing these activities to different groups of phytoconstituents but unspecifying the plant drug used. Also, Glensk et al.[35] reports the antimicrobial activity of PV rhizome attributed to osladin. It is widely known that the production of secondary metabolites is a response to environmental conditions (environmental stress, period of the year, among other variables) to which the plant is exposed[51].To eliminate this variable, the fronds from which the PVM was obtained in the present study were collected at the same time of the year (November 2016). Using HPLCDAD, we have determined a high number of polyphenolic substances and a small fraction of flavonoids (less than 15\% of the total polyphenolic species) represented by $(+)$-catechin hydrate, (-)-epicatechin, rutin and hyperoside. This observation agrees with our previous study using thin layer chromatography (TLC)[23]. It is well known that flavonoids, due to their radical scavenging ability provided by its chemical structure described elsewhere[52-54], have a greater antioxidant capacity than certain phenolic acids[55]; however, flavonoids are residual components of our PVM extract so the antioxidant activity of PVM could be attributed to a synergy among all polyphenolic compounds. Other phenolics such as $p$-coumaric, ferulic, caffeic, vanillic and chlorogenic acids, were reported as the major polyphenol phytocompounds in PLE by Gombau et al.[56] and as Garcia et al.[29]. Another important aspect to consider is the synergy that the different phytoconstituents present in an extract against oxidative damage[57,58].

In traditional medicine, especially in the Asian continent, a variety of ferns have been used as remedies as the case of the Gu-Sui-Bu ferns[59]. However, other fern species contain ptaquiloside, such as Pteridium aquilinum (L.) Kuhn (Dennstaedtiaceae family), which can cause cancer[60,61]. Currently, the potential beneficial effects but also the adverse and undesirable ones of PVM are unknown. For this reason, the objective of the present work is to study the biological activity of the PVM including its cytotoxic behavior in non-tumoral (3T3 and HaCaT) and tumoral cells (HeLa, HepG2, MCF-7 and A549) as a first step to explore the potential use as anticancer remedy. The activity of the extract against radical species produced in various diseases and pathological entities is also studied by different assays. Four concentrations of the PVM extract $(0.01,0.1,1$ and $2 \mathrm{mg} / \mathrm{mL}$ ) were selected in this preliminary study.

The possible use of natural fern extracts for anticancer therapy, as the case of some Asiatic fern species, has been demonstrated by the cytotoxic, pro-apoptotic or cell cyclearresting effects of non-characterized plant extracts[62]. In our case, no relevant cytotoxic 
effects have been reported for the extract in the different cell lines, except in the case of the HaCaT cells, but only at the highest concentrations assayed. Our PVM phytochemical characterization (HPLC-DAD) indicates that epicatechin is the second major compound of the flavonoid components of the extract. Moreover, Cao et al.[24] described a strong cytotoxic behavior of an ethanol extract of the whole fern Davallia cylindrica Ching (Davalliaceae family) in A549 cells that was attributed to the high content of quercetin and its derivatives. Using HPLC-DAD we failed to detect quercitrin (a derivative sugar of quercetin), which can explain the absence of relevant cytotoxicity together with the in chemico antioxidant potency[23]. Considering these outcomes, we design some assays to evaluate the possible chemopreventive effect of our PVM extract in cancer[18] and topical uses, that is cytoprotection, ROS production and phototoxicity assays. For these assays, only $3 \mathrm{~T} 3$ and HaCaT cells were used. Results obtained with these in vitro assays using these two cell lines open the possibility to validate the traditional use of this in the Sobrarbe region (Huesca)[40], mostly considering that fibroblasts, the most common cells in connective tissue, play a critical role in wound healing and keratinocytes form epidermis, which is a biological and physical barrier against injuries.

The potential protective effect of the PVM extract was assessed against hydrogen peroxide in $3 \mathrm{~T} 3$ and $\mathrm{HaCaT}$ cells. Our results show that $\mathrm{H}_{2} \mathrm{O}_{2}$ causes slightly higher mortality in $3 \mathrm{~T} 3$ (30.5\% cell viability) than in $\mathrm{HaCaT}$ ( $41.0 \%$ cell viability) that can be explained by a higher antioxidant defense system on keratinocytes than fibroblasts[63]. This minor mortality of the positive control in $\mathrm{HaCaT}$ can explain that the extract failed to present cytoprotective capacity in such cell line. We only have observed a discrete cytoprotective effect of PVM in the 3T3 cells being the first report that deals with this kind of assays using a fern extract from the Polypodiaceae family. However, Gomes et al.[64] and Gombau et al.[56] have described the potential antioxidant activity of PLE, an extract of the fronds of a Polypodiaceae fern, by in chemico and in vitro methods. Considering our results of cytoprotection, the cellular repair test was only performed in the 3T3 cell line. This assay showed that there is a significant increase in cellular viability directly proportional to PVM concentration suggesting the capacity of the extract to induce cellular repair mechanisms.

Alonso-Lebrero et al.[65] reported that PLE was able to protect human fibroblast from cytoskeletal disarrangements induced by UVA light $\left(1 \mathrm{~J} / \mathrm{cm}^{2}\right)$. Moreover, Philips et al.[66] reported that a concentration lower than 0.1\% PLE improves cellular membrane integrity and inhibits MMP-1 on fibroblast and keratinocytes thus suggesting its potential use in prevention on skin photoaging. However, before studying the potential photoprotective activity of the extract, we should discard any phototoxic reactions. In the present study, the determination of phototoxicity is based on the OECD TG 432[67], where the $\mathrm{BALB} / \mathrm{c} 3 \mathrm{~T} 3$ cell line has been replaced by NIH $3 \mathrm{~T} 3$ and we included the HaCaT cell line and the determination of cell viability by MTT as previously reported by other authors as Baccarin et al.[68]. In general, we can conclude that the PVM extract is not phototoxic although the decrease in cell viability at $0.1 \mathrm{mg} / \mathrm{mL}$ PVM in both cell lines needs to be clarified. One explanation could arise from the direct toxic effects of UVA light over the cells that can be reverted by the presence of the extract at high concentrations but not at moderate ones as $0.1 \mathrm{mg} / \mathrm{mL}$ PVM. Further investigation should be conducted to explore the cellular mechanisms that are activated. Contact time of the extract also should be considered, thus in this phototoxicity test is one hour plus the time of UVA exposition, whereas in the rest of assays the extract remains approximately $24 \mathrm{~h}$ in contact with cells.

It is known that UV damages mitochondrial DNA[69], for this reason it would be interesting to also evaluate the potential phototoxic or photoprotective activity of the PVM by other assays such as the comet assay in a similar way as previously described for Punica granatum L. (Lythraceae family) seed oil nanoemulsion in HaCaT[68]. Currently, the mechanisms of PLE's preventive effect against UV-induced DNA damage, such as overexpression of the p53 gene, have already been described as chemopreventive agent[70]. However, the importance of carrying out the comet assay in PVM is justified by the classification of the fern species Pteridium aquilinum (L.) Kuhn (Dennstaedtiaceae family) in group 2B 
by the International Agency for Research on Cancer (IARC), as possibly carcinogenic to humans, consequence to its potential capacity for DNA damage mainly induced by ptaquiloside [71].

Hydrogen peroxide is an oxidative agent that promote the endogenous generation of ROS in diverse cell lines[72]. If ROS trigger cell death by dramatically toxic concentrations, the loss of mitochondrial functionality begins with the consequent apoptosis[73]. In our case, there is an increase of ROS production in both cell lines except at $2 \mathrm{mg} / \mathrm{mL}$ in the case of 3T3 which can be related to the not significant cell viability increase observed in irradiated 3T3 treated with this PVM concentration (see Table 4). This increase of ROS production observed here and, particularly in HaCaT cell line apart from the lowest concentration extract tested $(0.01 \mathrm{mg} / \mathrm{mL}$ PVM), may be explained by the pro-oxidant effect of polyphenols[74]. The mechanism why this ROS can diminish cell viability needs to be clarified and further explored in other tumoral cell lines as a first step to better characterize chemotherapeutic potential of PVM[75].

\section{Materials and Methods}

We have designed the present work based on the experience of our group in the evaluation of the biological activity of both plant extracts and phytochemicals isolated from them[76,77]. Thus, considering FernBlock ${ }^{\circledR}$ as a reference of a protective fern against oxidative stress[65], we have evaluated the biological activity (cytotoxicity, cytoprotection, cellular repair, phototoxicity and ROS production) of the methanolic fronds extract of Polypodium vulgare L. (PVM) collected in the Prades Mountains. In parallel, we have also characterized the phytochemical composition of the fern extract by HPLC-DAD.

\subsection{Chemicals and reagents}

All reagents were of analytical grade. Trypan blue $(0.4 \%)$ dye, hydrogen peroxide $\left(\mathrm{H}_{2} \mathrm{O}_{2}\right)$ 30\% w/w, 2,5-diphenyl-3-(4,5-dimethyl-2-thiazolyl) tetrazolium bromide (MTT), dimethylsulfoxide (DMSO), 2,7-dichlorodihydrofluorescein diacetate (DCF) and chlorpromazine hydrochloride (CPZ, CAS № 69-09-0) were supplied from Sigma-Aldrich (Madrid, Spain). Dulbecco's modified Eagle's medium (DMEM) with and without phenol red, fetal bovine serum (FBS), phosphate buffered saline (PBS), L-glutamine solution (200 $\mathrm{mM})$, trypsin-ethylenediaminetetraacetic acid (EDTA) solution (170,000 U/L trypsin and $0.2 \mathrm{~g} / \mathrm{L}$ EDTA) and penicillin-streptomycin solution (10,000 U/mL penicillin and 10 $\mathrm{mg} / \mathrm{mL}$ streptomycin) were acquired from Lonza (Verviers, Belgium). All analytical standards used for liquid chromatography analysis shikimic acid, gallic acid, 5-Ocaffeoylquinic acid, 3-O-caffeoylquinic acid, (+)-catechin hydrate, (-)-epicatechin, rutin, hyperoside, naringin, quercitrin, 3,5-di-O-caffeoylquinic acid, rosmarinic acid, cinnamic acid, eugenol and trans-cinnamaldheyde were purchased from Sigma-Aldrich (Milan, Italy). The $75 \mathrm{~cm}^{2}$ culture flasks and 96-well plates were obtained from TPP (Trasadingen, Switzerland). HyClone fetal bovine serum (FBS) was purchased from Thermo Scientific (Northumberland, UK).

\subsection{Plant material}

The fronds of Polypodium vulgare L. (PV) were collected from the Prades Mountains $41^{\circ} 17^{\prime} 34^{\prime \prime} \mathrm{N} 1^{\circ} 02^{\prime} 42^{\prime \prime} \mathrm{E}$ geographical coordinates (Tarragona, Spain); the authors previously verified that this species was reported in the selected area by Banco de Datos de Biodiversidad de Cataluña[78]. When the fronds were dried, a sample voucher was stored at Herbarium of Universidad San Jorge (Zaragoza, Spain), Polypodium vulgare L.: voucher n⿳0 003-2016.

\subsection{Preparation of methanolic fronds extract of Polypodium vulgare L. (PVM)}

Powdered fronds of the plant material were macerated with methanol for 24 hours. After this, the methanolic extract was filtered using a Whatman №4 filter paper and to evaporate the solvent, a rotatory evaporator with a thermostatic bath at $30^{\circ} \mathrm{C}$ was used. This process was repeated three times to obtain the correspondence exhaustion extract as described by Farràs et al. 2019[23]. Finally, extracts were conserved at $-20^{\circ} \mathrm{C}$ until we need. 
Homogenization of the plant extract with the corresponding culture medium was obtained by sonication.

\subsection{Phytochemical characterization by liquid chromatography with diode-array detection (HPLC-DAD)}

HPLC-DAD studies were performed using a Hewlett-Packard HP-1090 Series II (Palo Alto, CA, USA), equipped with a vacuum degasser, a binary pump, an autosampler and a model 1046A HP photodiode array detector (DAD) following a previous developed method with some modifications[79]. The chromatographic separation was accomplished on a Synergi Polar-RP C18 (4.6 mm x $250 \mathrm{~mm}, 4 \mu \mathrm{m})$ analytical column from Phenomenex (Chesire, UK). The column was preceded by a security cartridge. The mobile phase for HPLC-DAD (diode array detector) analyses was a mixture of $(\mathrm{A})$ water with $0.1 \%$ formic acid $(\mathrm{v} / \mathrm{v})$ and $(\mathrm{B})$ acetonitrile with $0.1 \%$ formic acid, flowing at $0.8 \mathrm{~mL} / \mathrm{minutes}$ in gradient conditions: 0 minutes, 20\% B; 0-15 minutes, $60 \%$ B; $15-20$ minutes, 60\% B; 20-25 minutes, $20 \% \mathrm{~B}, 25-30$ minutes, $20 \% \mathrm{~B}$. The column temperature was set at $30^{\circ} \mathrm{C}$ and the injection volume was $5 \mu \mathrm{L}$. UV spectra were recorded in the range $230-350 \mathrm{~nm}$, where $230 \mathrm{~nm}$ was used for quantification of shikimic acid, $256 \mathrm{~nm}$ for rutin and hyperoside, $272 \mathrm{~nm}$ for gallic acid, $280 \mathrm{~nm}$ for (+)-catechin hydrate and (-)-epicatechin, $325 \mathrm{~nm}$ for 3-O-caffeoylquinic acid, 5-O-caffeoylquinic acid and 3,5-di-O-caffeoylquinic acid.

\subsection{Cell culture}

The mouse fibroblast cell line, NIH 3T3, and the spontaneously immortalized human keratinocyte cell line, $\mathrm{HaCaT}$, were used in all in vitro experiments. In the case of cytotoxic assay, cell viability also was evaluated by the cervical cancer cell line HeLa, the liver cancer cell line HepG2, the breast cancer cell line MCF-7 and lung cancer cell line A549. 3T3 and A549 were purchased from Sigma-Aldrich as a worldwide provider of European Collection of Authenticated Cell Cultures (ECACC), whereas HaCaT, HeLa and MCF-7 were obtained from Eucellbank (Celltec-Universitat de Barcelona, Spain). HepG2 cell line was kindly donated by Dr. Borràs of Experimental Toxicology and Ecotoxicology Platform (UTOX-CERETOX) of Parc Científic of Universitat de Barcelona. Cells lines were maintained in Dulbecco's modified Eagle's medium (DMEM) and 4.5 g/L glucose red (DMEM) was supplemented with $10 \%$ heat-inactivated fetal bovine serum (FBS), $2 \mathrm{mM}$ L-glutamine and $100 \mathrm{U} / \mathrm{mL}: 100 \mathrm{U} / \mathrm{mL}$ streptomycin-penicillin mixture $\left(10 \%\right.$ FBS-DMEM) at $37^{\circ} \mathrm{C}$ in a $5 \%$ carbon dioxide $\left(\mathrm{CO}_{2}\right)$-humidified incubator. Cells were routinely subcultured in $75 \mathrm{~cm}^{2}$ flasks. When cells reached $80 \%$ of confluence, culture medium was removed, cells were rinsed with PBS and then detached by trypsinization (trypsin-EDTA). Then, $100 \mu \mathrm{L}$ of the cell suspension $\left(1 \times 10^{5}\right.$ cells $\left./ \mathrm{mL}\right)$ were seeded in 96 well microplates and incubated overnight $\left(37^{\circ} \mathrm{C}\right.$ and $\left.5 \% \mathrm{CO}_{2}\right)$. Cell density was previously established by the trypan blue $(0.4 \%)$ dye exclusion method form the cell suspension obtained after trypsinization.

\subsection{Determination of cell viability by NRU and MTT assays}

Cell viability were determined by the NRU and MTT methods after treatments.

The Borenfreund and Puerner protocol for the determination of cell viability by NRU has been followed with some described adaptations [80]. Once the incubation time of the cells with the treatments had elapsed, the supernatant was extracted from each well and $100 \mu \mathrm{L}$ of NR solution was applied $(0.05 \mathrm{mg} / \mathrm{mL}$ in DMEM $0 \%$ FBS without phenol red). After three hours, the supernatant was removed by inversion from the plate and $100 \mu \mathrm{L}$ of the developer NR solution was added. In the developer solution, the formaldehyde was replaced by an acidic ethanol solution as described by Riddell et al.[81]. The quantification of the remnant NR, which corresponds to the NRU bound to the lysosomes, is proportional to the viable cells[82]. After 5 to 10 minutes of shaking the plate, the absorbance was obtained at $550 \mathrm{~nm}$, by means of the Tecan Sunrise microplate reader (Männedorf, Switzerland).

The MTT assay based on the experimental protocol of Mosmann[83] was used with the adaptations of Zanette et al.[84]; $100 \mu \mathrm{L}$ of an MTT solution $(0.5 \mathrm{mg} / \mathrm{mL}$ in $0 \%$ FBS- 
DMEM without phenol red) was added in each well following incubation of the plates for at least $3 \mathrm{~h}$ in cell culture incubation conditions $\left(37^{\circ} \mathrm{C}\right.$ and $\left.5 \% \mathrm{CO}_{2}\right)$. At the end of incubation, supernatant was removed and $100 \mu \mathrm{L}$ of the organic dissolvent dimethyl sulfoxide (DMSO) was added to each well to dissolve the formazan crystals[85]. The amount of soluble formazan is proportional to the number of cells with optimal mitochondrial activity[86]. Absorbance was measured at $550 \mathrm{~nm}$ using a Tecan Sunrise ${ }^{\circledR}$ microplate reader (Männedorf, Switzerland), previous homogenization of the well content by gently shaking each microplate during 5 minutes at $100 \mathrm{rpm} / \mathrm{min}$.

Cell viability for NRU and MTT assays were calculated using the following equation: Cell viability $(\%)=\left(\left(A_{\text {control }}-A_{\text {sample }}\right) / A_{\text {control }}\right) \times 100 \%$

where $A_{\text {control }}$ and $A_{\text {sample }}$ are the absorbance of the control and each sample, respectively.

4.6.1. Cytotoxicity activity of PVM in non-tumoral and tumoral cells lines

Non-tumoral (3T3 and HaCaT) and tumoral cells lines (HeLa, HepG2, MCF-7 and A549) were treated for $24 \mathrm{~h}\left(37^{\circ} \mathrm{C}\right.$ and $\left.5 \% \mathrm{CO}_{2}\right)$ with increasing concentrations of methanolic extract $0.01,0.1,1$ and $2 \mathrm{mg} / \mathrm{mL}$ PV in 5\% FBS-DMEM. In each plate, untreated cells (maintained with culture medium) were included as negative controls. Cytotoxicity of PVM was determined by the NRU and MTT assays.

4.6.2. Cytoprotective and cellular repair activity of PVM in non-tumoral cell lines

In these experiments, oxidative stress was induced using hydrogen peroxide after treatment (cytoprotection) or before extract treatment (cellular reparation)[87].

4.6.2.1 Cytoprotective activity in $3 \mathrm{~T} 3$ and HaCaT cell lines

Cells were pre-treated with $0.01,0.1,1$ and $2 \mathrm{mg} / \mathrm{mL}$ PVM $(100 \mu \mathrm{L})$ dissolved by 5\% FBS-DMEM for $24 \mathrm{~h}$ following addition of $\mathrm{H}_{2} \mathrm{O}_{2}$ (in 5\% FBS-DMEM) at a final concentration $2 \mathrm{mM}$ for $2.5 \mathrm{~h}$. Finally, cell viability was determined by NRU and MTT assay. In each microplate negative and positive controls were included. In this case, positive controls consist of cells treated by $\mathrm{H}_{2} \mathrm{O}_{2}$ at $2 \mathrm{mM}$ during $2.5 \mathrm{~h}$ without previous pre-treatment with the extracts.

Cytoprotective activity was calculated as follows:

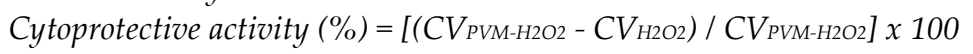

where $C V$ is the cell viability for each condition described in the formula.

4.6.2.2. Cellular repair activity in $3 \mathrm{~T} 3$ cells

$18 \mathrm{~h}$ after the cell seeding the corresponding oxidative stress agent $\left(100 \mu \mathrm{L} \mathrm{H}_{2} \mathrm{O}_{2}\right.$ at 2 $\mathrm{mM}$ during $2.5 \mathrm{~h}$ ) were applied in the cellular repair assay. Then, the same treatment concentrations of the extract in the previous cytoprotective assay were applied. After $24 \mathrm{~h}$ incubation, cell viability was assessed by NRU and MTT assays.

Cellular repair activity was calculated as follows:

Cellular repair activity $(\%)=\left[\left(C V P V M-\mathrm{H}_{2} \mathrm{O} 2-\mathrm{CVH}_{\mathrm{H} 2 \mathrm{O}}\right) / \mathrm{CV}\right.$ PVM-H2O2 $] x 100$

where $C V$ is the cell viability for each condition described in the formula.

4.6.3. Phototoxicity activity in $3 \mathrm{~T} 3$ and $\mathrm{HaCaT}$ cell lines

We followed the Organization for Economic Cooperation and Development (OECD) TG 432 (2019)[67] with some adaptions. Briefly, 3T3 and HaCaT cells were plated at a density of $1 \times 10^{5}$ cells/mL $(100 \mu \mathrm{L})$ in a 96 well microplate in 10\% FBS-DMEM for $24 \mathrm{~h}$ and then treated with 0.01, 0.1, 1 and $2 \mathrm{mg} / \mathrm{mL}$ PVM $(100 \mu \mathrm{L})$. PVM samples were solubilized in a $0 \%$ FBS-DMEM without phenol red, while negative and positive controls consisted in cells no treated and treated with chloropromazine $(37.5 \mu \mathrm{g} / \mathrm{mL}$ chlorpromazine) in $0 \%$ FBS-DMEM without phenol red, respectively. Cells were incubated for 1 hour and after that, one plate remain in the dark and other received $1.8 \mathrm{~J} / \mathrm{cm}^{2}$ of ultraviolet A (UVA) light. At the end of UVA light medium was replaced for $100 \mu \mathrm{L}$ of fresh medium $(10 \%$ FBS-DMEM) and cell viability was determined after $24 \mathrm{~h}$ of incubation by the NRU and MTT colorimetric assays.

Light exposure was performed in a photostability UV chamber $(58 \times 34 \times 28 \mathrm{~cm})$ equipped with three UVA lamps Actinic BL TL/TL-D/T5 (Philips ${ }^{\circledR}, 43 \mathrm{~V}, 352 \mathrm{~nm}, 15 \mathrm{~W}$ ) as 
described in Martínez et al.[88]. Dosage and time exposition of cells to UVA light was regularly settled thanks to a photoradiometer Delta OHM provided with a UVA probe (HD2302 - Italy). We followed the equation:

$$
E\left(\mathrm{~J} / \mathrm{cm}^{2}\right)=t(\mathrm{~s}) \times P\left(\mathrm{~W} / \mathrm{cm}^{2}\right)
$$

where $E$ stands for ultraviolet dose, $t$ represents the time expressed in seconds and, finally, $P$ is the lamp potency.

\subsection{Intracellular reactive oxygen species (ROS) induced by H2O2 of PVM in $3 \mathrm{~T} 3$ and HaCaT cell lines}

The production of ROS generated by $\mathrm{H}_{2} \mathrm{O}_{2}$ over a range of time was determined according to Ferreira et al.[89], for ROS assay. After the incubation of the cells with the different concentrations of the extract for $24 \mathrm{~h}$ as reported in previous sections for in vitro assays, cells were washed twice with PBS and DCF $(100 \mu \mathrm{M})$ was applied to each well for 45 minutes $\left(37^{\circ} \mathrm{C}\right.$ and $\left.5 \% \mathrm{CO}_{2}\right)$. DCF that has not penetrated cells was removed by washing twice with cell culture medium and then $\mathrm{H}_{2} \mathrm{O}_{2}(1$ and $2 \mathrm{mM}$ ) was added to induce oxidative stress. The fluorescence intensity of the oxidized product of DCF was registered $\left(\left(\lambda_{\text {excitation }} 480 \mathrm{~nm} ; \lambda_{\text {emision }} 530 \mathrm{~nm}\right)\right.$ at $0,1,2$ and $3 \mathrm{~h}$ by a plate reader ThermoFisher SCIENTIFIC VARIOSKAN LUX (ThermoFisher SCIENTIFIC, Waltham, Massachusetts, USA). Results were expressed as Fluorescence Intensity (FI) which have adimensional units. The $\mathrm{FI}_{\mathrm{z}} \mathrm{Vs} 0 \mathrm{~h}$ were calculated as follows:

Fluorescence Intensityz $V_{s} 0_{h}\left(F I_{z h v_{0} h}\right)=\left[\left(F I_{z h}-F I_{0 h}\right) / F I_{z h}\right] \times 100$

where $F I_{z h}$ is the intensity fluorescence at $z \mathrm{~h}(z$ as $1 \mathrm{~h}, 2 \mathrm{~h}$ or $3 \mathrm{~h})$ of incubation and $F I_{0}$ the amount fluorescence intensity at $0 \mathrm{~h}$.

The FI for each specific time was calculated using this formula:

$$
F I=\text { Fluorescence } 480 \mathrm{~nm} \text { (excitation) / Fluorescence } 480 \mathrm{~nm} \text { (emission) }
$$

The $\triangle R O S$, which have adimensional units for FI, was obtained using the following formula:

$$
\triangle \mathrm{ROS}_{\mathrm{H} 2 \mathrm{O} 2}=\mathrm{ROS}_{P V M} \text { with } \mathrm{DCF}-\mathrm{H} 2 \mathrm{O} 2-\mathrm{ROS}_{D C F-\mathrm{H} 2 \mathrm{O} 2}
$$

\subsection{Statistical analysis}

All experiments were carried out in triplicates and almost 3 independent experiments were assayed, on different days, except for the cytoprotection PVM HaCaT against $2 \mathrm{mM}$ $\mathrm{H}_{2} \mathrm{O}_{2}$ (2.5 h) MTT for which the results correspond to $\mathrm{n}=2$ experiments, respectively. Statistical significance for MTT cell viability and fluorescence intensity was analysed by using GraphPad Prism version 7, San Diego, CA, USA. Data are presented as mean +/- standard error. Activities have been compared using a two-way analysis of variance (ANOVA) by Bonferroni. Statistical differences were considered as follows: $p \leq 0.05\left({ }^{*}\right), p \leq 0.01\left({ }^{* *}\right)$, $p \leq 0.001\left(^{* * *}\right)$ and $p \leq 0.0001\left(^{* * * *}\right)$.

\section{Conclusions}

In conclusion, PVM extract show biological activity at similar concentrations used in previous in vitro studios with PLE[43]. The antioxidant-prooxidant behavior described here with different assays, encourage us to continue PVM evaluation to discover and describe potential chemopreventive uses.

Author Contributions: Conceptualization M.M. and V.L.; methodology, A.F., M.M., F.M.; analysis, A.F., F.M., G.C., M.M.; investigation, A.F., M.M., V.L.; resources, M.M., P.V., V.L; writing-original draft preparation, A.F.; writing - review and editing, M.M. and V.L.; supervision, M.M., and V.L; funding acquisition M.M. and P.V. All authors have read and agreed to the published version of the manuscript.

Funding: This work was financially supported by project 307629 of Fundació Bosch \& Gimpera Universitat de Barcelona.

Acknowledgements: We acknowledge the technical support of Universitat de Barcelona and Universidad San Jorge.

Conflicts of Interest: The authors declare that they do not have any conflicts of interest. 


\section{Abreviations}

\begin{tabular}{|c|c|}
\hline $3 \mathrm{~T} 3=\mathrm{NIH} 3 \mathrm{~T} 3$ & mouse fibroblast cell line \\
\hline A549 & lung cancer cell line \\
\hline $\mathrm{CO}_{2}$ & carbon dioxide \\
\hline $\mathrm{CV}$ & cell viability \\
\hline CPZ & chlorpromazine hydrochloride \\
\hline $\mathrm{E}$ & ultraviolet dose \\
\hline EMA & European Medicines Agency \\
\hline DCF & 2,7-dichlorodihydrofluorescein diacetate \\
\hline DMEM & dulbecco's modified Eagle's medium \\
\hline DMSO & dimethyl sulfoxide \\
\hline EDTA & ethylenediaminetetraacetic acid \\
\hline ECACC & European Collection of Authenticated Cell Cultures \\
\hline FBS & fetal bovine serum \\
\hline FI & fluorescence intensity \\
\hline $\mathrm{HaCaT}$ & spontaneously immortalized human keratinocyte cell line \\
\hline HeLa & cervical cancer cell line \\
\hline HepG2 & liver cancer cell line \\
\hline HPLC-DAD & liquid chromatography with diode-array detection \\
\hline $\mathrm{H}_{2} \mathrm{O}_{2}$ & hydrogen peroxide \\
\hline MCF-7 & breast cancer cell line \\
\hline MTT & 2,5-diphenyl-3-(4,5-dimethyl-2-thiazolyl) tetrazolium bromide \\
\hline NR & neutral red \\
\hline NRU & neutral red uptake \\
\hline OECD & economic cooperation and development \\
\hline PBS & phosphate buffered saline \\
\hline PL & Polypodium leucotomos \\
\hline PLE & aqueous extract of Polypodium leucotomos \\
\hline PV & Polypodium vulgare L. \\
\hline PVM & methanolic extract of Polypodium vulgare L. \\
\hline ROS & reactive oxygen species \\
\hline RNS & reactive nitrogen species \\
\hline TLC & thin layer chromatography \\
\hline UV & ultraviolet \\
\hline UVA & ultraviolet A \\
\hline
\end{tabular}

\section{References}

1. Addor, F.A.S. Antioxidants in dermatology. Anais Brasileiros De Dermatologia 2017, 92, 356-362, doi:10.1590/abd1806-4841.20175697.

2. Halliwell, B.; Gutteridge, J.M.C. Free radicals in biology and medicine. Free radicals in biology and medicine 2015, 944 pp.

3. Willcox, J.K.; Ash, S.L.; Catignani, G.L. Antioxidants and prevention of chronic disease. Critical Reviews in Food Science and Nutrition 2004, 44, 275-295, doi:10.1080/1008690490468489.

4. He, L.; He, T.; Farrar, S.; Ji, L.B.; Liu, T.Y.; Ma, X. Antioxidants Maintain Cellular Redox Homeostasis by Elimination of Reactive Oxygen Species. Cellular Physiology and Biochemistry 2017, 44, 532-553, doi:10.1159/000485089. 
5. Casedas, G.; Les, F.; Gomez-Serranillos, M.P.; Smith, C.; Lopez, V. Bioactive and functional properties of sour cherry juice (Prunus cerasus). Food \& Function 2016, 7, 4675-4682, doi:10.1039/c6fo01295g.

6. Virgili, F.; Marino, M. Regulation of cellular signals from nutritional molecules: a specific role for phytochemicals, beyond antioxidant activity. Free Radical Biology and Medicine 2008, 45, 1205-1216, doi:10.1016/j.freeradbiomed.2008.08.001.

7. Evans, J.A.; Johnson, E.J. The Role of Phytonutrients in Skin Health. Nutrients 2010, 2, 903-928, doi:10.3390/nu2080903.

8. Kimlin, M.G.; Guo, Y.M. Assessing the impacts of lifetime sun exposure on skin damage and skin aging using a non-invasive method. Science of the Total Environment 2012, 425, 35-41, doi:10.1016/j.scitotenv.2012.02.080.

9. Gegotek, A.; Domingues, P.; Skrzydlewska, E. Natural Exogenous Antioxidant Defense against Changes in Human Skin Fibroblast Proteome Disturbed by UVA Radiation. Oxidative Medicine and Cellular Longevity 2020, 2020, doi:10.1155/2020/3216415.

10. Rundle, C.W.; Militello, M.; Barber, C.; Presley, C.L.; Rietcheck, H.R.; Dellavalle, R.P. Epidemiologic Burden of Skin Cancer in the US and Worldwide. Current Dermatology Reports 2020, 9, 309-322, doi:10.1007/s13671-02000311-4.

11. Leiter, U.; Keim, U.; Eigentler, T.; Katalinic, A.; Holleczek, B.; Martus, P.; Garbe, C. Incidence, Mortality, and Trends of Nonmelanoma Skin Cancer in Germany. Journal of Investigative Dermatology 2017, 137, 1860-1867, doi:10.1016/j.jid.2017.04.020.

12. Markovits, J.; Linassier, C.; Fosse, P.; Couprie, J.; Pierre, J.; Jacqueminsablon, A.; Saucier, J.M.; Lepecq, J.B.; Larsen, A.K. INHIBITORY EFFECTS OF THE TYROSINE KINASE INHIBITOR GENISTEIN ON MAMMALIAN DNA TOPOISOMERASE-II. Cancer Research 1989, 49, 5111-5117.

13. Tatsuta, M.; Iishi, H.; Baba, M.; Yano, H.; Murata, K.; Mukai, M.; Akedo, H. Suppression by apigenin of peritoneal metastasis of intestinal adenocarcinomas induced by azoxymethane in Wistar rats. Clinical $\mathcal{E}$ Experimental Metastasis 2001, 18, 657-662.

14. Di Pietro, A.; Conseil, G.; Perez-Victoria, J.M.; Dayan, G.; Baubichon-Cortay, H.; Trompier, D.; Steinfels, E.; Jault, J.M.; de Wet, H.; Maitrejean, M.; et al. Modulation by flavonoids of cell multidrug resistance mediated by Pglycoprotein and related ABC transporters. Cellular and Molecular Life Sciences 2002, 59, 307-322, doi:10.1007/s00018-002-8424-8.

15. Ren, W.Y.; Qiao, Z.H.; Wang, H.W.; Zhu, L.; Zhang, L. Flavonoids: Promising anticancer agents. Medicinal Research Reviews 2003, 23, 519-534, doi:10.1002/med.10033.

16. Newman, D.J.; Cragg, G.M. Natural Products As Sources of New Drugs over the 30 Years from 1981 to 2010. Journal of Natural Products 2012, 75, 311-335, doi:10.1021/np200906s.

17. Silva, V.A.O.; Alves, A.L.V.; Rosa, M.N.; Silva, L.R.V.; Melendez, M.E.; Cury, F.P.; Gomes, I.N.F.; Tansini, A.; Longato, G.B.; Martinho, O.; et al. Hexane partition from Annona crassiflora Mart. promotes cytotoxity and apoptosis on human cervical cancer cell lines. Investigational New Drugs 2019, 37, 602-615, doi:10.1007/s10637018-0657-y.

18. Asensi, M.; Ortega, A.; Mena, S.; Feddi, F.; Estrela, J.M. Natural polyphenols in cancer therapy. Critical Reviews in Clinical Laboratory Sciences 2011, 48, 197-216, doi:10.3109/10408363.2011.631268.

19. Alvarado-Sansininea, J.J.; Sanchez-Sanchez, L.; Lopez-Munoz, H.; Escobar, M.L.; Flores-Guzman, F.; TaveraHernandez, R.; Jimenez-Estrada, M. Quercetagetin and Patuletin: Antiproliferative, Necrotic and Apoptotic Activity in Tumor Cell Lines. Molecules 2018, 23, 18, doi:10.3390/molecules23102579.

20. Shukla, S.; Meeran, S.M.; Katiyar, S.K. Epigenetic regulation by selected dietary phytochemicals in cancer chemoprevention. Cancer Letters 2014, 355, 9-17, doi:10.1016/j.canlet.2014.09.017. 
21. Cao, J.; Xia, X.; Dai, X.; Xiao, J.; Wang, Q.; Andrae-Marobela, K.; Okatch, H. Flavonoids profiles, antioxidant, acetylcholinesterase inhibition activities of extract from Dryoathyrium boryanum (Willd.) Ching. Food and Chemical Toxicology 2013, 55, 121-128, doi:10.1016/j.fct.2012.12.051.

22. Chear, N.J.-Y.; Khaw, K.-Y.; Murugaiyah, V.; Lai, C.-S. Cholinesterase inhibitory activity and chemical constituents of Stenochlaena palustris fronds at two different stages of maturity. Journal of Food and Drug Analysis 2016, 24, 358-366, doi:10.1016/j.jfda.2015.12.005.

23. Farras, A.; Casedas, G.; Les, F.; Terrado, E.M.; Mitjans, M.; Lopez, V. Evaluation of Anti-Tyrosinase and Antioxidant Properties of Four Fern Species for Potential Cosmetic Applications. Forests 2019, 10, 14, doi:10.3390/f10020179.

24. Cao, J.G.; Xia, X.; Dai, X.L.; Wang, Q.X.; Xiao, J.B. Chemical composition and bioactivities of flavonoids-rich extract from Davallia cylindrica Ching. Environmental Toxicology and Pharmacology 2014, 37, 571-579, doi:10.1016/j.etap.2014.01.011.

25. Cardenas, A.V.C.; Hernandez, L.R.; Juarez, Z.N.; Sanchez-Arreola, E.; Bach, H. Antimicrobial, cytotoxic, and anti-inflammatory activities of Pleopeltis polylepis. Journal of Ethnopharmacology 2016, 194, 981-986, doi:10.1016/j.jep.2016.10.071.

26. Banerjee, R.D.; Sen, S.P. ANTIBIOTIC-ACTIVITY OF PTERIDOPHYTES. Economic Botany 1980, 34, 284-298, doi:10.1007/bf02858649.

27. Choudhry, S.Z.; Bhatia, N.; Ceilley, R.; Hougeir, F.; Lieberman, R.; Hamzavi, I.; Lim, H.W. Role of Oral Polypodium Leucotomos Extract in Dermatologic Diseases:A Review of the Literature. Journal of Drugs in Dermatology 2014, 13, 148-153.

28. Thompson, K.G.; Kim, N. Dietary supplements in dermatology: Areview of the evidence for zinc, biotin, vitamin D, nicotinamide, and Polypodium. Journal of the American Academy of Dermatology 2020, doi:10.1016/j.jaad.2020.04.123.

29. Garcia, F.; Pivel, J.P.; Guerrero, A.; Brieva, A.; Martinez-Alcazar, M.; Caamano-Somoza, M.; Gonzalez, S. Phenolic components and antioxidant activity of Fernblock ${ }^{\circledR}$, an aqueous extract of the aerial parts of the fern Polypodium leucotomos. Methods and Findings in Experimental and Clinical Pharmacology 2006, 28, 157-160, doi:10.1358/mf.2006.28.3.985227.

30. List, T.P. Polypodium vulgare L. Available online: http://www.theplantlist.org/tpl1.1/record/tro-26600283 https://www.ipni.org/n/300720-2 (accessed on 20-01-2021).

31. Bolòs, O.; Vigo, J. Flora dels Països Catalans I. In Polipodiàcies: Polypodium vulgare L.; Editorial Barcino: 1984; pp. 188-190.

32. Quer, P.F. Plantas Medicinales. El Dioscórides renovado. In PTERIDÓFITOS: POLIPODIO (Polypodium vulgare L.), Península, Ed.; Ediciones Península: 2016; pp. 73-75.

33. Khare, C. Polypodium vulgare Linn. . In: Khare C. (eds) Indian Medicinal Plants; C., K., Ed.; Springer: New York, NY, 2007.

34. EMA. Assessment report on Polypodium vulgare L., rhizoma 2008, Evaluation of Medicines for Human Use. EMEA/HMPC/600669/2007.

35. Glensk, M.; Tichaczek-Goska, D.; Sroda-Pomianek, K.; Wlodarczyk, M.; Wesolowski, C.A.; Wojnicz, D. Differing antibacterial and antibiofilm properties of Polypodium vulgare L. Rhizome aqueous extract and one of its purified active ingredients-osladin. Journal of Herbal Medicine 2019, 17-18, doi:10.1016/j.hermed.2019.100261.

36. Bonet, M.À.; Vallès, J. Ethnobotany of Montseny biosphere reserve (Catalonia, Iberian Peninsula): Plants used in veterinary medicine. Journal of Ethnopharmacology 2007, 110, 130-147, doi:https://doi.org/10.1016/j.jep.2006.09.016.

37. AEMPS. PROSPECTO: INFORMACIÓN PARA EL PACIENTE Difur 120 mg cápsulas duras. $2013,4$. 
38. Parrado, C.; Philips, N.; Gilaberte, Y.; Juarranz, A.; Gonzalez, S. Oral Photoprotection: Effective Agents and Potential Candidates. Frontiers in Medicine 2018, 5, 19, doi:10.3389/fmed.2018.00188.

39. Chen, C.; Kong, A.N.T. Dietary cancer-chemopreventive compounds: from signaling and gene expression to pharmacological effects. Trends in Pharmacological Sciences 2005, 26, 318-326, doi:10.1016/j.tips.2005.04.004.

40. Villar, L.; Bonet, M.À. Polypodium L. In Inventario Español de los Conocimientos Tradicionales relativos a la Biodiversidad, 2 ed.; Pardo de Santayana, M., Morales, R., Tardío, J., Molina, M., Eds.; Ministerio de Agricultura y Pesca, Alimentación y Medio Ambiente de España: Madrid, 2018; Volume Segunda Fase, Tomo I, pp. 51-55.

41. Chai, T.T.; Elamparuthi, S.; Yong, A.L.; Quah, Y.; Ong, H.C.; Wong, F.C. Antibacterial, anti-glucosidase, and antioxidant activities of selected highland ferns of Malaysia. Botanical Studies 2013, 54, 7, doi:10.1186/1999-311054-55.

42. Gonzalez, S.; Gilaberte, Y.; Philips, N. Mechanistic insights in the use of a Polypodium leucotomos extract as an oral and topical photoprotective agent. Photochemical $\mathcal{E}$ Photobiological Sciences 2010, 9, 559-563, doi:10.1039/b9pp00156e.

43. Palomino, O.M. Current knowledge in Polypodium leucotomos effect on skin protection. Archives of Dermatological Research 2015, 307, 199-209, doi:10.1007/s00403-014-1535-x.

44. Messeguer, J.; Melé, E.; Reixach, N.; Irurre-Santilari, J.; Casas, J. Polypodium vulgare L. (Wood Fern): In Vitro Cultures and the Production of Phytoecdysteroids. In Medicinal and Aromatic Plants X, Y.P.S., B., Ed.; Biotechnology in Agriculture and Forestry; Springer: Berlin, Heidelberg, 1998; Volume 41, pp. 333-348.

45. Liu, B.; Diaz, F.; Bohlin, L.; Vasange, M. Quantitative determination of antiinflammatory principles in some Polypodium species as a basis for standardization. Phytomedicine 1998, 5, 187-194, doi:10.1016/s09447113(98)80026-3.

46. Glensk, M.; Dudek, M.K.; Ciach, M.; Wlodarczyk, M. Isolation and structural determination of flavan-3-ol derivatives from the Polypodium vulgare L. rhizomes water extract. Natural Product Research, 10, doi:10.1080/14786419.2019.1655302.

47. Arai, Y.; Shiojima, K.; Ageta, H. Fern constituents: Cyclopodmenyl acetate, a cycloartanoid having a new 33carbon skeleton, isolated from Polypodium vulgare. Chemical and Pharmaceutical Bulletin 1989, 37, 560-562, doi:10.1248/cpb.37.560.

48. Arai, Y.; Yamaide, M.; Yamazaki, S.; Ageta, H. FERN CONSTITUENTS - TRITERPENOIDS ISOLATED FROM POLYPODIUM-VULGARE, POLYPODIUM-FAURIEI AND POLYPODIUM-VIRGINIANUM. Phytochemistry 1991, 30, 3369-3377, doi:10.1016/0031-9422(91)83212-4.

49. Dar, P.A.; Sofi, G.; Jafri, M.A. Polypodium vulgare Linn. a versatile herbal medicine: a review. International Journal of Pharmaceutical Sciences and Research (IJPSR) 2012, 3, 1616-1620.

50. Sofiane, G.; Wafa, N.; Ouarda, D. Antioxidant, antimicrobial and anti-inflammatory activities of flavonoids and tannins extracted from Polypodium vulgare L. Asian Journal of Biochemical and Pharmaceutical Research 2015, 5, 114122.

51. Wu, S.Q.; Li, J.; Wang, Q.X.; Cao, H.; Cao, J.G.; Xiao, J.B. Seasonal dynamics of the phytochemical constituents and bioactivities of extracts from Stenoloma chusanum (L.) Ching. Food and Chemical Toxicology 2017, 108, 458-466, doi:10.1016/j.fct.2016.10.003.

52. Rice-Evans, C.A.; Miller, N.J.; Paganga, G. Erratum: Structure-antioxidant activity relationships of flavonoids and phenolic acids (Free Radical Biology and Medicine (1996) 20 (933-956)). Free Radical Biology and Medicine 1996, 21, 417, doi:10.1016/S0891-5849(96)90046-5.

53. Prochazkova, D.; Bousova, I.; Wilhelmova, N. Antioxidant and prooxidant properties of flavonoids. Fitoterapia 2011, 82, 513-523, doi:10.1016/j.fitote.2011.01.018. 
54. Wen, L.R.; He, J.R.; Wu, D.; Jiang, Y.M.; Prasad, K.N.; Zhao, M.M.; Lin, S.; Jiang, G.X.; Luo, W.; Yang, B. Identification of sesquilignans in litchi (Litchi chinensis Sonn.) leaf and their anticancer activities. Journal of Functional Foods 2014, 8, 26-34, doi:10.1016/j.jff.2014.02.017.

55. Leopoldini, M.; Russo, N.; Toscano, M. The molecular basis of working mechanism of natural polyphenolic antioxidants. Food Chemistry 2011, 125, 288-306, doi:https://doi.org/10.1016/j.foodchem.2010.08.012.

56. Gombau, L.; Garcia, F.; Lahoz, A.; Fabre, M.; Roda-Navarro, P.; Majano, P.; Alonso-Lebrero, J.L.; Pivel, J.P.; Castell, J.V.; Gomez-Lechon, M.J.; et al. Polypodium leucotomos extract: Antioxidant activity and disposition. Toxicology in Vitro 2006, 20, 464-471, doi:10.1016/j.tiv.2005.09.008.

57. Yen, W.-J.; Chyau, C.-C.; Lee, C.-P.; Chu, H.-L.; Chang, L.-W.; Duh, P.-D. Cytoprotective effect of white tea against H2O2-induced oxidative stress in vitro. Food Chemistry 2013, 141, 4107-4114, doi:10.1016/j.foodchem.2013.06.106.

58. Naik, A.V.; Sellappan, K. In vitro evaluation of Annona muricata L. (Soursop) leaf methanol extracts on inhibition of tumorigenicity and metastasis of breast cancer cells. Biomarkers 2020, 25, 701-710, doi:10.1080/1354750x.2020.1836025.

59. Chang, H.-C.; Huang, G.-J.; Agrawal, D.C.; Kuo, C.-L.; Wu, C.-R.; Tsay, H.-S. Antioxidant activities and polyphenol contents of six folk medicinal ferns used as "Gusuibu". Botanical Studies 2007, 48, 397-406.

60. da Costa, R.M.G.; Bastos, M.M.S.M.; Oliveira, P.A.; Lopes, C. Bracken-associated human and animal health hazards: Chemical, biological and pathological evidence. Journal of Hazardous Materials 2012, 203, 1-12, doi:10.1016/j.jhazmat.2011.12.046.

61. O'Connor, P.J.; Alonso-Amelot, M.E.; Roberts, S.A.; Povey, A.C. The role of bracken fern illudanes in bracken fern-induced toxicities. Mutation Research-Reviews in Mutation Research 2019, 782, 39, doi:10.1016/j.mrrev.2019.05.001.

62. Tomsik, P. Ferns and LycopodsA Potential Treasury of Anticancer Agents but Also a Carcinogenic Hazard. Phytotherapy Research 2014, 28, 798-810, doi:10.1002/ptr.5070.

63. Perez, S.; Sergent, O.; Morel, P.; Chevanne, M.; Dubos, M.P.; Cillard, P.; Cillard, J. Kinetics of lipid peroxidation induced by UVB on epidermal cell cultures. Comptes Rendus des Seances de la Societe de Biologie et de ses Filiales 1995, 189, 453-465.

64. Gomes, A.J.; Lunardi, C.N.; Gonzalez, S.; Tedesco, A.C. The antioxidant action of Polypodium leucotomos extract and kojic acid: reactions with reactive oxygen species. Brazilian Journal of Medical and Biological Research 2001, 34, 1487-1494, doi:10.1590/S0100-879X2001001100018.

65. Alonso-Lebrero, J.L.; Dominguez-Jimenez, C.; Tejedor, R.; Brieva, A.; Pivel, J.P. Photoprotective properties of a hydrophilic extract of the fern Polypodium leucotomos on human skin cells. Journal of Photochemistry and Photobiology B-Biology 2003, 70, 31-37, doi:10.1016/s1011-1344(03)00051-4.

66. Philips, N.; Smith, J.; Keller, T.; Gonzalez, S. Predominant effects of Polypodium leucotomos on membrane integrity, lipid peroxidation, and expression of elastin and matrixmetalloproteinase-1 in ultraviolet radiation exposed fibroblasts, and keratinocytes. Journal of Dermatological Science 2003, 32, 1-9, doi:10.1016/s09231811(03)00042-2.

67. (OECD), O.f.E.C.a.D. OECD Test No. 432: In vitro 3T3 NRU Phototoxicity Test. Available online: https://www.oecd-ilibrary.org/environment/test-no-432-in-vitro-3t3-nru-phototoxicity-test_9789264071162-en jsessionid=1OLquVlgT3EB3I0UYnGoOSHf.ip-10-240-5-137 (accessed on 20-01-2021).

68. Baccarin, T.; Mitjans, M.; Ramos, D.; Lemos-Senna, E.; Vinardell, M.P. Photoprotection by Punica granatum seed oil nanoemulsion entrapping polyphenol-rich ethyl acetate fraction against UVB-induced DNA damage in human keratinocyte (HaCaT) cell line. Journal of Photochemistry and Photobiology B-Biology 2015, 153, 127-136, doi:10.1016/j.jphotobiol.2015.09.005. 
69. Hseu, Y.C.; Lo, H.W.; Korivi, M.; Tsai, Y.C.; Tang, M.J.; Yang, H.L. Dermato-protective properties of ergothioneine through induction of Nrf2/ARE-mediated antioxidant genes in UVA-irradiated Human keratinocytes. Free Radical Biology and Medicine 2015, 86, 102-117, doi:10.1016/j.freeradbiomed.2015.05.026.

70. Parrado, C.; Nicolas, J.; Juarranz, A.; Gonzalez, S. The role of the aqueous extract Polypodium leucotomos in photoprotection. Photochemical \& Photobiological Sciences 2020, 19, 831-843, doi:10.1039/d0pp00124d.

71. Gomes, J.; Magalhaes, A.; Michel, V.; Amado, I.F.; Aranha, P.; Ovesen, R.G.; Hansen, H.C.B.; Gaertner, F.; Reis, C.A.; Touati, E. Pteridium aquilinum and Its Ptaquiloside Toxin Induce DNA Damage Response in Gastric Epithelial Cells, a Link With Gastric Carcinogenesis. Toxicological Sciences 2012, 126, 60-71, doi:10.1093/toxsci/kfr329.

72. Uguz, A.C.; Oz, A.; Naziroglu, M. Curcumin inhibits apoptosis by regulating intracellular calcium release, reactive oxygen species and mitochondrial depolarization levels in SH-SY5Y neuronal cells. Journal of Receptors and Signal Transduction 2016, 36, 395-401, doi:10.3109/10799893.2015.1108337.

73. Moloney, J.N.; Cotter, T.G. ROS signalling in the biology of cancer. Seminars in Cell E Developmental Biology 2018, 80, 50-64, doi:10.1016/j.semcdb.2017.05.023.

74. Santos, J.S.; Deolindo, C.T.P.; Hoffmann, J.F.; Chaves, F.C.; do Prado-Silva, L.; Sant'Ana, A.S.; Azevedo, L.; do Carmo, M.A.V.; Granato, D. Optimized Camellia sinensis var. sinensis, Ilex paraguariensis, and Aspalathus linearis blend presents high antioxidant and antiproliferative activities in a beverage model. Food Chemistry 2018, 254, 348-358, doi:10.1016/j.foodchem.2018.02.021.

75. Skibola, C.F.; Smith, M.T. Potential health impacts of excessive flavonoid intake. Free Radical Biology and Medicine 2000, 29, 375-383, doi:10.1016/s0891-5849(00)00304-x.

76. Ugartondo, V.; Mitjans, M.; Lozano, C.; Torres, J.L.; Vinardell, M.P. Comparative study of the cytotoxicity induced by antioxidant epicatechin conjugates obtained from grape. Journal of Agricultural and Food Chemistry 2006, 54, 6945-6950, doi:10.1021/jf061356i.

77. Baccarin, T.; Mitjans, M.; Lemos-Senna, E.; Vinardell, M.P. Protection against oxidative damage in human erythrocytes and preliminary photosafety assessment of Punica granatum seed oil nanoemulsions entrapping polyphenol-rich ethyl acetate fraction. Toxicology in Vitro 2015, 30, 421-428, doi:10.1016/j.tiv.2015.09.020.

78. Font Castell, X. Banco de datos de biodiversidad de Cataluña. 2015, aprox. 2 pantallas.

79. Caprioli, G.; Alunno, A.; Beghelli, D.; Bianco, A.; Bramucci, M.; Frezza, C.; Iannarelli, R.; Papa, F.; Quessinti, L.; Sagratini, G.; et al. Polar Constituents and Biological Activity of the Berry-Like Fruits from Hypericum androsaemum L. Frontiers in Plant Science 2016, 7, doi:10.3389/fpls.2016.00232.

80. Borenfreund, E.; Puerner, J.A. TOXICITY DETERMINED INVITRO BY MORPHOLOGICAL ALTERATIONS AND NEUTRAL RED ABSORPTION. Toxicology Letters 1985, 24, 119-124, doi:10.1016/0378-4274(85)90046-3.

81. Riddell, R.J.; Clothier, R.H.; Balls, M. AN EVALUATION OF 3 INVITRO CYTOTOXICITY ASSAYS. Food and Chemical Toxicology 1986, 24, 469-471, doi:10.1016/0278-6915(86)90095-5.

82. Weyermann, J.; Lochmann, D.; Zimmer, A. A practical note on the use of cytotoxicity assays. International Journal of Pharmaceutics 2005, 288, 369-376, doi:10.1016/j.ijpharm.2004.09.018.

83. Mosmann, T. RAPID COLORIMETRIC ASSAY FOR CELLULAR GROWTH AND SURVIVAL APPLICATION TO PROLIFERATION AND CYTO-TOXICITY ASSAYS. Journal of Immunological Methods 1983, 65, 55-63, doi:10.1016/0022-1759(83)90303-4.

84. Zanette, C.; Pelin, M.; Crosera, M.; Adami, G.; Bovenzi, M.; Larese, F.F.; Florio, C. Silver nanoparticles exert a long-lasting antiproliferative effect on human keratinocyte HaCaT cell line. Toxicology in Vitro 2011, 25, 10531060, doi:10.1016/j.tiv.2011.04.005.

85. Präbst, K. Cell Viability Assays. In Basic Colorimetric Proliferation Assays: MTT, WST, and Resazurin, First ed.; Gilbert, D.F., Friedrich, O., Eds.; Springer: New York, 2017; pp. 1-17. 
86. Fotakis, G.; Timbrell, J.A. In vitro cytotoxicity assays: Comparison of LDH, neutral red, MTT and protein assay in hepatoma cell lines following exposure to cadmium chloride. Toxicology Letters 2006, 160, 171-177, doi:10.1016/j.toxlet.2005.07.001.

87. Casedas, G.; Les, F.; Choya-Foces, C.; Hugo, M.; Lopez, V. The Metabolite Urolithin-A Ameliorates Oxidative Stress in Neuro-2a Cells, Becoming a Potential Neuroprotective Agent. Antioxidants 2020, 9, 16, doi:10.3390/antiox9020177.

88. Martinez, V.; Galbiati, V.; Corsini, E.; Martin-Venegas, R.; Vinardell, M.P.; Mitjans, M. Establishment of an in vitro photoassay using THP-1 cells and IL-8 to discriminate photoirritants from photoallergens. Toxicology in Vitro 2013, 27, 1920-1927, doi:10.1016/j.tiv.2013.06.013.

89. Ferreira, I.; Silva, A.; Martins, J.D.; Neves, B.M.; Cruz, M.T. Nature and kinetics of redox imbalance triggered by respiratory and skin chemical sensitizers on the human monocytic cell line THP-1. Redox Biology 2018, 16, 75-86, doi:10.1016/j.redox.2018.02.002. 